\title{
DEVELOPING WRITING MATERIALS FOR DEAF STUDENTS
}

\author{
Hamdan Anwari \\ Sekolah Tinggi Pariwisata AMPTA, Yogyakarta \\ hamdan.to.you@gmail.com
}

\begin{abstract}
This research is aimed at finding out the suitable writing material for deaf students. This research belongs to research and development. The participants of this research were the eleventh graders of SLB Muhammadiyah Dekso Kalibawang of semester 1 in academic year 2013/2014 that consisted of two students. The instruments used in collecting data were questionnaires. The questionnaires were used in the needs analysis, material evaluation and students' response. The data were analyzed descriptively by using percentage. Based on the needs analysis, it was found out that students' need was suitable for writing material. In developing syllabus, existing syllabus must be added with some exercises. The developed material was in the form of hand out. The writing handout material was for the deaf students. The developed material was for the first semester academic year of 2013/2014 that consisted of three units, five topics and nineteen activities. After being evaluated by two ecperts, the developed materials were appeared to facilitate the deaf students to write. Based on the student's response, the developed material was appropriate to their English level competence.
\end{abstract}

Keywords: Developing material, writing skill, deaf student

\section{INTRODUCTION}

Language is one of the gifts given by God. Language is used to make interaction among speakers as means of communication. Crystal (1997: 3) says that English is a global language. It becomes one of the compulsory subjects, which is taught in school. It is the first foreign language which is taught not only in lementary, junior school, senior high school and university but also special needs school that is called by Sekolah Luar Biasa (SLB). While in elementary level English becomes a local content subject, in junior school and senior high school it is a compulsory subject that serves as a means to develop science and technology. There are four skills in English, they are listening, speaking, reading and writing. 
The objective of teaching English in Indonesia is to enable students to use English for communication. The ability to communicate in English becomes an important skill. The success in teaching and learning process can not be separated from the factors related to the process of teaching and learning. There are five factors influencing teaching and learning process namely student, teacher, method, media and material.

Material is the key factor that is emphasized to elaborate this discussion. Material plays an important role to be succeed in teaching and learning process. According to Tomlinson (2008, p. 2), teaching material is the term that refers to anything used by teachers or learners to facilitate the learning of a language. Richard (2001, p. 251) says that teaching materials were the key component in the most language program. They provided ideas on how to plan and teach lesson as well as formats that teacher can use. In the other words, materials will influence the other teaching and learning components.

Teaching English material can be in the form of a textbook, a workbook, a cassette, a CD-Rom, a video, a photocopied handout, a newspaper and many others. In SLB Muhammadiyah Kalibawang, some English materials in this school are not suitable for the students. One of the English materials that are needed by students in SLB Muhamadiyah Kalibawang is textbook.

Textbooks is one type of texts a book used in an educational curriculum. A textbook contains the information of knowledge or certain course. A textbook or course book is a manual of instruction in any branch of studies. Textbooks are produced according to the demands of educational institutions. They are crucial factors for quality education, especially in developing countries.

In SLB Muhammadiyah Kalibawang, the material to learn English is not suitable for the students. It is necessary to develop materials which are suitable and relevant to the students' level. There is no specific textbook or material for them. The available materials are sometimes difficult for the students. The teachers only adopt the material from other schools without considering the appropriateness of the material for the students in this 
school. The students' need in SLB Muhammadiyah Kalibawang is different from the others. Deaf students need material that is completed with visual media to learn English, especially speaking. Meanwhile, English writing materials for the deaf studentsshould consist of units, tasks, and activities.

Based on the problem formulation the objectives of the study are stated as follows:

A. To find out the students' need in learning writing at SLB Muhammadiyah Dekso Kalibawang Kulon Progo in the Academic year of $2013 / 2014$.

B. To describe the steps of constructing English writing material for deaf students at SLB Muhammadiyah Dekso Kalibawang Kulon Progo in the Academic year of $2013 / 2014$.

C. To find the form of English writing material for deaf students at SLB Muhammadiyah Dekso Kalibawang Kulon Progo in the Academic year of $2013 / 2014$.

D. To find out the response of English writing material for deaf students at SLB Muhammadiyah Dekso Kalibawang Kulon Progo in the Academic year of $2013 / 2014$.

Parahoo (1997) defines research design as a plan that describes how, when and where data are to be collected and analyzed. Ary (2006) points out that the educational researches are typically classified into two broad categories, thay are quantitative and qualitative research. Borg (1988) mentions that the Research and Development (R\&D) is a kind of research method in education.

Shohamy (1989) states that quantitative research is the judgment of test quantified as statistic and it becomes the data. It begins by identifying educational patters by assessing or measuring individual abilities, collecting scores from individuals and employing procedures of psychological experiments and large-scale surveys.

According to Cresswell (2008), qualitative research is a type of educational research in which the researcher relies on the views of participants asks broad, general question, collect the data consisting largely of words (or text) from participants; describes and analyzes these words for 
themes and conduct the inquiry in a subject, biased manner. It seeks to understand the participants' experience. Meanwhile, Research and Development (R\&D) is a kind of research to make the goal to be applicable nd adaptable. Research and development (R\&D) develops the quality of education.

Borg (1983) says that educational research and development is a process to develop and validate educational product. Research and Development $(\mathrm{R} \& \mathrm{D})$ is a method of investigation where it is assumed that new scientific knowledge is discovered due to a series of linear and sequential stages that consists of basic research, applied research and development.

Research and Development (R\&D) is a process to develop and validate educational product. $R \& D$ is a series of action accustomed to develop educational product and validate by testing the product. This research does not to test theories and hypothesis, but to develop effective and appropriate product to use in school. This research is also aimed at using the research findings to design new product and procedures as an industry based development model. Gay (1981) states that Research and Development is not to formulate or test theory but to develop effective product used in the educational program. The product includes teacher training material, learning material and set of behavioral objectives, media, material etc.

Research and Development (R\&D) becomes a cycle that consists of studying research findings pertinent to the product to be developed, developing product based on this findings, field testing in the setting where it will be used eventually, and revising it to correct the deficiencies found in the field-testing stage. The researcher develops English writing material for deaf students at SLB Muhammadiyah Kalibawang that belongs to Research and Development research.

This research was conducted in SLB Muhammadiyah Dekso Kalibawang. There were two deaf students of eleventh grade students of the first semester in the academic year of 2013/2014. Wilkinson and Peter (2003) defines research instruments are simply devices for obtaining 
information relevant to the research project. There are many alternatives from which to choose. Ary (2007) states, there are the three basic types of datagathering instruments; they are observation, interview and questionnaire. In this study, researcher employed three questionnaires as instruments in developing the material; they were the questionnaires for need analysis, review from the expert and for evaluation.

Questionnaire for Need Analysis

The first questionnaire was for needs analysis. In this stage, questionnaire was aimed at obtaining information about the students' need and interest in learning English, especially in writing. The researcher should have information about what the students needed and about their opinion on writing material and the difficulty that they encounter. This questionnaire consisted of fifteen questions. The questionnaires were in the form of multiple choice. The students were ordered to choose one or more alternatives answers by crossing A, B, C, or D. In conducting the questionnaire the researcher used multiple choice question $S$ Likert scale to collect the data. The option of questionnaires used four categories, they were strongly disagree, disagree, agree and strongly agree.

Questionnaire for Material Review from the Expert

The second questionnaire was used in the material reviews stage. According to Klein and Richey (2007), material review depends on expert opinion to produce descriptive data. It was done by delivering the questionnaire to the experts. There were twenty one questions to deliver. The analysis of questionnaire was in the form of Likert Scale. There were four options to decide the level of questionnaire analysis. They were strongly agree, agree, disagree and strongly disagree. Cunningsworth (1995) proposes that the questionnaire in this study is developed based on the material evaluation. The outlines of the questionnaire in this study were aim and purpose, design and organization, language content, skill, methodology and practical consideration. 
Questionnaire for Material Evaluation

The third questionnaire was for material evaluation. According to Tomlinson (2008), material evaluation is motivated by the need to choose material will be relevant and appropriate for a particular group of learner and also by the need to identify specific aspect to the material that require adaptation. In this stage this instrument was used to know the students' opinion on the material. There were fifteen questions. Those questions contain aspects of aim and purpose, topic, organization, practical consideration and result of using material. The questionnaire was distributed to the students at the end of the tried-out. It was designed to know the students' opinion on the material. Then, the result of the questionnaire was used to evaluate the draft of the material. The questions were developed in the form of Likert Scale by using four options. They were strongly agree, agree, disagree and strongly disagree. All of the questions were developed based on checklist of evaluating and selecting material from Cunningsworth (1995) and the theory of material evaluation from Tomlinson (1998).

\section{DISCUSSSION}

Need Analysis

Need analysis in this research was done by using a questionnaire to gather the data. This research was addressed to deaf students of eleventh grade students at SLB Muhammadiyah Kalibawang. There were two deaf students in this class. In conducting need analysis the researcher used a questionnaire which consisted of twelve questions as follows: 
Table 1 . The result of need analysis

\begin{tabular}{|c|c|c|c|c|c|}
\hline No & Statements & $\begin{array}{l}\text { Strongly } \\
\text { Agree }\end{array}$ & Agree & Disagree & $\begin{array}{l}\text { Strongly } \\
\text { Disagree }\end{array}$ \\
\hline 1 & I need a better writing material. & & $100 \%$ & & \\
\hline 2 & $\begin{array}{l}\text { The available writing material } \\
\text { motivates me to learn writing. }\end{array}$ & & & $100 \%$ & \\
\hline 3 & $\begin{array}{l}\text { Materials and learning activities I have } \\
\text { in the class help me to learn writing } \\
\text { successfully. }\end{array}$ & & & $50 \%$ & $50 \%$ \\
\hline \multirow[t]{2}{*}{4} & It is necessary to have examples of & $50 \%$ & $50 \%$ & & \\
\hline & the genre text. & & & & \\
\hline 5 & The available topics are interesting. & & & $100 \%$ & \\
\hline 6 & The writing activities should be step by & $50 \%$ & $50 \%$ & & \\
\hline 7 & I find it difficult to learn functional text. & $50 \%$ & $50 \%$ & & \\
\hline 8 & Media are needed to learn writing. & $100 \%$ & & & \\
\hline 9 & I need more suitable material to learn & $100 \%$ & & & \\
\hline 10 & I need various activities of writing & $100 \%$ & & & \\
\hline 11 & The available material is interesting to & & & $100 \%$ & \\
\hline 12 & The available material is attractive in its & & & $100 \%$ & \\
\hline
\end{tabular}

From the question one, it can be seen that the students need better writing material to learn writing. In relation to the availability of the writing material, it can be concluded that the students need suitable material to learn writing. In the materials and learning activities they have in the class learn, students need better material and activity to help their learning writing. With regard to the necessity to have examples of the genre text, students need some examples of it. They need interesting topics to learn writing. The students also need writing activities which are done in step by step.

The students need more explanation to learn functional text material in order to understand it better. The need for media in learning writing is crucial, as well as the need for more suitable and attractive materials.

\section{Syllabus Design}

The researcher designed a syllabus applied for deaf students in teaching. it consists of a competence standard, basic competence, indicator, character and culture indicator, learning material, learning activity, assessment, time allocation and sources. The competence standard of this 
designed syllabus expresses a meaning in a functional written text and monologue/short essay in the form of procedure and report to interact in daily life.

The designed syllabus consists of three basic competences. The basic competences are made up in the form of showing the meaning found in the functional text and monologue/short essay, using the meanings in a simple functional text, for example a letter, advertisement and announcement, and using the meaning and rhetorical step in form of monologue text/the simple essay in form of procedure and report. This designed syllabus consists of six indicators; they are to arrange jumble sentences into a good paragraph, write a letter and the procedure text, discuss things which are related to the topic, write short functional texts, write functional texts and arrange jumble sentences into a good paragraph. The character building of this designed syllabus includes well behaved and precise. The learning materials of the syllabus are writing a jumble paragraph, identifying parts of letter, writing a letter, writing a text procedure paragraph, identifying an advertisement, writing an advertisement, identifying the parts of announcement, writing an announcement, identifying report text, discussing the topic, writing short sentences about simple present and writing short a short report text.

This designed syllabus also consists of learning activities. They are identifying parts of letter, discussing the vocabularies and some expressions which are used in the text, arranging the jumble sentences into a good paragraph in the form functional text/short essay, discussing things which are related to the theme and the topic of genre text, writing an advertisement, discussing things which are related to the topic, analyzing an example of functional text, and writing the short sentence. The form of assessment in this designed syllabus is written test. The material is delivered in four meetings and each meeting has forty minutes.

\section{Developed Material}

Tomlinson (1998, p. 4) states that material development refers to 
anything done by writers or teachers to provide source of language input to exploit those sources in ways which maximize the likehood of intake. Developing material is based on the results of the need analysis because it takes a broad perspective for designed material. Thomas (2001) says that a developed material is a material dealing with a definite subject of study, systematically arranged, intended for use at a specified level of instruction, and used a principal source of study material for a given course.

In this research, the material consists of three units, five topics and nineteen activities. The first unit consists of two topics; they are how to make letter and how to make instant noodle. Both topics include nine activities. The activities are reading the dialogue about how to write a letter. It becomes pre activity in the first topic. Beside reading a dialogue, the other activity is filling the parts of the letter. This activity asks the students to arrange a good letter with available sentences. The next activity is rearranging the jumbled sentences. In this stage, the students write a complete letter. The second topic is writing how to make instant noodle. The activity is in the form of reading procedure text. It becomes a pre activity. The next activity is matching the verbs based on the picture. Beside matching the verbs, there is a lesson of sentence connectors. There are some sentence connectors which are used to write procedure text. The last activity in the first material is writing a complete procedure text by using available sentence connectors.

The second unit consists of two topics and seven activities. The topics are writing an announcement and writing an advertisement. The activities of writing an advertisement include reading an example of advertisement. While reading an advertisement, students are asked to recognize what is advertized. After that, there is an activity of analyzing the parts of the advertisement. In this stage, the student activity is to arrange jumbled sentences to be a good advertisement. The next is studying the announcement with its parts. The last is completing the announcement using the given words and writing incomplete announcement with a different topic.

The third unit of materials consists of one topic which is reporting is 
report text. It includes four activities they are reading the report text and analyzing the generic structure of report text. Those become pre activity of the material. After reading the report text, the further activity is filling the parts of report text. This activity asks the students to know the generic structure as characteristic of report text. The next activity is completing the paragraph. In this activity some words are provided. It aims at making a paragraph with the given word easier.

\section{Trying Out the Material}

To obtain the information from the learners, the writer employed a try out. The function of the tried-out stage is to evaluate the product or the designed material whether it is suitable for deaf students or not. In this study, the researcher selected some units to be tried out in the classroom.

There were two deaf students of eleventh grade students of the first semester in the academic year of 2013/2014 at SLB Muhammadiyah Dekso Kalibawang. This school is located at Dekso Plono street, Km 01. In the try out, the researcher needed three meetings with time duration of forty minutes for each meeting. It was held on first, second and third of September 2014, at 08.30 to 09.10 a.m. There were two units that were taught. Those included how to write a letter, how to make instant noodle, writing an advertisement and writing an announcement.

Evaluating the materials from the experts

To evaluate the developed material, the writer distributed a questionnaire to two experts. The questionnaire is in the form of multiple choice and consists of twelve questions. The questions of the questionnaire are in the form of Likert Scale with four options. They are based on the categories. Those include strongly agree (4), agree (3), disagree (2) and strongly disagree (1). The result of material evaluation is as follows: 
Table 2. The result of material evaluation from the experts

\begin{tabular}{llcc}
\hline No & \multicolumn{1}{c}{ Statements } & Expert A & Expert B \\
\hline 1 & $\begin{array}{l}\text { The material facilitates the student to learn } \\
\text { how to express learning and rhetorical } \\
\text { steps of written text essays in the form }\end{array}$ & 3 & 3 \\
\hline 2 & $\begin{array}{l}\text { The material is in line with the } \\
\text { learning objectives. }\end{array}$ & 3 & 4 \\
\hline 3 & $\begin{array}{l}\text { The material covers most or all of } \\
\text { what is needed in teaching writing. }\end{array}$ & 3 & 4 \\
\hline 4 & The content is organized logically. & 4 & 3 \\
\hline 5 & The material is systematically designed. & 4 & 3 \\
\hline 6 & The material is arranged with difficulty level. \\
\hline 7 & The material is suitable for individual study. & 3 & 3 \\
\hline 8 & The layout of material is clear. & 3 & 3 \\
\hline 9 & $\begin{array}{l}\text { The material covers vocabulary } \\
\text { teaching, adequate in terms of quality } \\
\text { and range of vocabulary. }\end{array}$ & 3 & 3 \\
\hline 10 & The material develops writing skill. & 3 & 3 \\
\hline 11 & $\begin{array}{l}\text { The topics used in the material are } \\
\text { interesting. }\end{array}$ & 3 & 3 \\
\hline 12 & $\begin{array}{l}\text { The topics help the student's awareness } \\
\text { and enrich the experience in learning }\end{array}$ & 3 & 3 \\
\hline 13 & $\begin{array}{l}\text { The material covers the activities in } \\
\text { teaching writing. }\end{array}$ & 3 & 4 \\
\hline 14 & $\begin{array}{l}\text { The material encourages the students } \\
\text { to be active in their learning. }\end{array}$ & 3 & 3 \\
\hline 15 & $\begin{array}{l}\text { The material develops the students' } \\
\text { communicative ability. }\end{array}$ & 3 & 3 \\
\hline 16 & The material is attractive in appearance. & 3 & 3 \\
\hline 17 & The instructions are clear. & 3 & 3 \\
\hline & $\quad$ & 3 & 3 \\
\hline
\end{tabular}

In relation to the material, both experts say that the material facilitates the students to learn how to express learning and rhetorical steps of written text essays in the form genre of text. Concerning to the learning objectives, it can be seen that the material is in line with the learning objectives. In terms of the teaching material in writing both experts state that the material covers what is needed in teaching writing. Talking about the organization of the content from the material, both experts mention that the content is organized logically and the material is systematically designed. With regard to the arrangement of the difficulty level, both experts state that the book is arranged with difficulty level. In relation to the suitability of material for individual study, both experts claim that the material is 
suitable for individual study. The clear layout of the material means that the layout is good.

With regard to the material that covers vocabulary teaching, both experts state that the material covers vocabulary teaching adequately. In relation to the material that develops writing skill, both experts say that the material develops student's skill to write. Dealing with the topics, both experts explain that ite topics are interesting and are also able to help students enrich their experience in learning writing. Talking about the scope of materials, both experts claim that the material covers the activities in teaching writing and the activities are relevant. In accordance with encourage the students to be active in their learning, the material encourages the students to be active in learning writing. The developed material develops the students' communicative ability. In the appearance of the material, it can be seen that the materials are attractive enough, which means that the instructions are easily understood.

The Response to the Developed Material

In analyzing this data, the researcher employed an instrument which was in the form of a questionnaire. The data were analyzed descriptively. Technique of analyzing this data was by using percentage. The aim of distributing the instruments was to know about the students' opinion on the material. In conducting this stage, a questionnaire was distributed to the students at the end of the try out. The questionnaire was adopted from Likert Scale. The result of the questionnaire is as follows: 
Table 3. The result of students' response to the constructed material

\begin{tabular}{|c|c|c|c|c|c|}
\hline \multirow[t]{2}{*}{ No } & \multirow[t]{2}{*}{ Statement } & \multicolumn{4}{|c|}{ Category } \\
\hline & & $\begin{array}{l}\text { Strongl } \\
\mathrm{y}\end{array}$ & Agree & Disagree & $\begin{array}{l}\text { Strongl } \\
\mathrm{y}\end{array}$ \\
\hline 1. & $\begin{array}{l}\text { The material is appropriate } \\
\text { with my English level }\end{array}$ & & $100 \%$ & & \\
\hline 2 & $\begin{array}{l}\text { The material motivates me } \\
\text { to learn writing. }\end{array}$ & & $100 \%$ & & \\
\hline 3 & $\begin{array}{l}\text { The material helps me to solve } \\
\text { the difficulty in learning }\end{array}$ & & $100 \%$ & & \\
\hline 4 & The topics are interesting. & $50 \%$ & $50 \%$ & & \\
\hline 5 & $\begin{array}{l}\text { The activities in the material } \\
\text { are suitable with my need. }\end{array}$ & $50 \%$ & $50 \%$ & & \\
\hline 6 & $\begin{array}{l}\text { The activities are arranged } \\
\text { from the simple to the complex }\end{array}$ & & $100 \%$ & & \\
\hline 7 & $\begin{array}{l}\text { The material makes me active } \\
\text { in learning writing. }\end{array}$ & $50 \%$ & $50 \%$ & & \\
\hline 8 & The instructions are clear. & & $100 \%$ & & \\
\hline 9 & The vocabulary section helps & $50 \%$ & $50 \%$ & & \\
\hline 10 & The text of the material is & $50 \%$ & $50 \%$ & & \\
\hline 11 & The activities are varied. & & $100 \%$ & & \\
\hline 12 & The layout is interesting. & $100 \%$ & & & \\
\hline
\end{tabular}

In relation to the appropriateness of te material, both students state that the material is appropriate with their English level competence. Concerning to the developed material, both students state that the developed material motivates them to learn writing. It can be seen from the difficulty of material, both students mention that the material helps them solve the difficulty in learning writing.

Regarding to the interesting topic, the students respond that the topics are interesting. In accordance with the appropriateness of activities, both students claim that the activities in the material are appropriate with their need. In relation to the arrangement of activities, the students infer that the activities are arranged from the simple to the complex ones. In accordance with the attractive material, they say that the material makes them active in learning writing. Talking about the appearance of the developed material, they state that the instructions are clear.Concerning with the layout, they mention that the material is interesting and readable. Dealing with vocabulary section, they state that it 
helps them write English. Regard to the various activities, they say that the activities are varied.

\section{CONCLUSION}

The Steps of Material Development

Need Analysis

The researcher carried out a need analysis to know the deaf student's need in learning writing. The result of the need analysis was that the deaf students need some better writing material.

\section{Syllabus Design}

The designed syllabus consists of a competence standard, basic competence, indicator, character and culture indicator, learning material, learning activity, assessment, time allocation and sources.

Material Development

The developed material is in the form of hand out for the deaf students. The developed material is for the first semester academic year of $2013 / 2014$. It consist of thee unites, five topics and nineteen activities. The five topics in this material are How to write letter, make noodle, write an advertisement, an announcement and report text This study includes nineteen activities they are dentifying the genre of text, completing paragraph, rearranging jumbled sentence and writing whole paragraphs. In this developed material, The vocabularies are given to certain topics.

\section{Try-Out}

In this study the researcher selected some units to be tried out in the classroom. The researcher tried out the writing material to the two deaf students of eleventh grade students of the first semester in the academic year of 2013/2014 of SLB Muhammadiyah Dekso Kalibawang. In the try out, the researcher needed three meetings with time duration of forty minutes for each meeting. It was held on first, second and third of 
September 2014, at 08.30 to 09.10 a.m. They were two units which were taught. Those included how to write a letter, how to make noodle, writing an advertisement an writing an announcement report text.

Experts' Judgment

In this study, both experts said that the material facilitates the students to learn writing. The material is in line with the learning objectives. It covers what is needed in teaching writing. The content is organized logically. It is systematically designed and arranged with difficulty level. The material is suitable for individual study. The layout of material is clear. The material covers vocabulary teaching.

They said that the material develops writing skill. The topics used in the material are interesting. The topics help the student's awareness and enrich the experience in learning writing. The material covers the activities in teaching writing. It encourages the students to be active in their learning. It develops the students' communicative ability. It is attractive in appearance. The instructions are clear.

\section{Students' Response}

Based on the student's response, the developed material is appropriate with their English level competence. The material motivates the to learn writing. The material helps them to solve the difficulty in learning writing. The topics of developed material are interesting. The activities in the material are suitable with their need. The activities are arranged from the simple to the complex topic. The material makes them active in learning writing. The instructions are clear. The vocabulary section helps them in writing English. The text of the material is readable. The activities are varied. The layout is interesting. 


\section{EduLite}

Journal of English Education, Literature, and Culture

Volume 2, Number 2, August 2017

\section{REFERENCES}

Ary, D. (2006). Introduction to research in education. USA: Wadsworth.

Borg,W. (1981). Applying education research a practical guide. New York: Longman.

Cresswell. (2008). Educational research. USA: Pearson.

Crystal, D. (1997). English as a global language. Cambridge: Cambridge University Press.

Cunningsworth, A. (1995). Choosing your course book. Oxford: Heineman.

Gall et.al. (1982). Educational research; an introduction, USA: Longman Publisher.

Gay, L, R. (1981). Educational research competencies for analysis and application. Toronto: McMilian Publishing Company

Richards, J. C. (1990). Conversationally speaking: approaches to the teaching of the conversion. In Jack C. Richards. The Language Teaching Matrix. New York: Cambridge University Press.

Richards, J.C. and Renandya, W. A. (2002). Methodology in language teaching: An anthology of current practice. Cambridge: Cambridge University Press.

Richey, C.R. and Klein, D.J. (2007). Design and development research. Florida: Routledge.

Tomlinson, B. (2008). Material development in language teaching. Cambridge: Cambridge University Press.

Wilkinson, D and Peter, B. 2003. Using research instruments; a guide for researcher. London: Routledge. 